\title{
BACTERIA DIVERSITY AND MICROBIAL BIOMASS IN FOREST, PASTURE AND FALLOW SOILS IN THE SOUTHWESTERN AMAZON BASIN ${ }^{(1)}$
}

\author{
Karina Cenciani ${ }^{(2)}$, Marcio Rodrigues Lambais ${ }^{(3)}$, $\operatorname{Carlos}_{\text {Clemente Cerri }}{ }^{(4)}$, \\ Lucas Carvalho Basílio de Azevedo ${ }^{(5)}$ \& Brigitte Josefine Feigl ${ }^{(6)}$
}

\begin{abstract}
SUMMARY
It is well-known that Amazon tropical forest soils contain high microbial biodiversity. However, anthropogenic actions of slash and burn, mainly for pasture establishment, induce profound changes in the well-balanced biogeochemical cycles. After a few years the grass yield usually declines, the pasture is abandoned and is transformed into a secondary vegetation called "capoeira" or fallow. The aim of this study was to examine how the clearing of Amazon rainforest for pasture affects: (1) the diversity of the Bacteria domain evaluated by Polymerase Chain Reaction and Denaturing Gradient Gel Electrophoresis (PCR-DGGE), (2) microbial biomass and some soil chemical properties ( $\mathrm{pH}$, moisture, $\mathrm{P}, \mathrm{K}, \mathrm{Ca}, \mathrm{Mg}, \mathrm{Al}, \mathrm{H}+\mathrm{Al}$, and $\mathrm{BS}$ ), and (3) the influence of environmental variables on the genetic structure of bacterial community. In the pasture soil, total carbon (C) was between 30 to $42 \%$ higher than in the fallow, and almost $47 \%$ higher than in the forest soil over a year. The same pattern was observed for $\mathrm{N}$. Microbial biomass in the pasture was about 38 and $26 \%$ higher than at fallow and forest sites, respectively, in the rainy season. DGGE profiling revealed a lower number of bands per area in the dry season, but differences in the structure of bacterial communities among sites were better defined than in the wet season. The bacterial DNA fingerprints in the forest were stronger related to $\mathrm{Al}$ content and the Cmic:Ctot and Nmic:Ntot ratios. For pasture and fallow sites, the structure of the Bacteria domain was more associated
\end{abstract}

\footnotetext{
(1) Trabalho extraído de tese de doutorado do primeiro autor e financiado pela FAPESP. Recebido para publicação em abril de 2008 e aprovado em maio de 2009.

${ }^{(2)}$ Doutoranda do Programa de Pós-Graduação em Microbiologia Agrícola, Escola Superior de Agricultura "Luiz de Queiroz" ESALQ/USP. Caixa Postal 9, Av. Pádua Dias 11, CEP 13418-900 Piracicaba (SP). Bolsista CAPES. E-mail: kcencian@gmail.com

${ }^{(3)}$ Pesquisador do Departamento de Solos e Nutrição Mineral de Plantas, ESALQ/USP. E-mail: mlambais@esalq.usp.br

(4) Pesquisador do Laboratório de Biogeoquímica Ambiental. Universidade de São Paulo - USP. Centro de Energia Nuclear na Agricultura - CENA. Caixa Postal 96, Av. Centenário 303, CEP 13400-970 Piracicaba (SP). E-mail: cerri@cena.usp.br

(5) Doutorando do Programa de Pós-Graduação em Solos e Nutrição Mineral de Plantas, Escola Superior de Agricultura "Luiz de Queiroz" - ESALQ/USP. Caixa Postal 9, Av. Pádua Dias 11, CEP 13418-900 Piracicaba (SP). E-mail: lcbazevedo@yahoo.com.br

${ }^{(6)}$ Pesquisador do Laboratório de Biogeoquímica Ambiental, CENA. E-mail: beduardo@cena.usp.br
} 
with $\mathrm{pH}$, sum of bases, moisture, total $\mathrm{C}$ and $\mathrm{N}$ and the microbial biomass. In general microbial biomass in the soils was influenced by total $\mathrm{C}$ and $\mathrm{N}$, which were associated with the Bacteria domain, since the bacterial community is a component and active fraction of the microbial biomass. Results show that the genetic composition of bacterial communities in Amazonian soils changed along the sequence forest-pasture-fallow.

Index terms: land use changes; PCR-DGGE; bacterial diversity; microbial biomass; principal component analysis.

\title{
RESUMO: DIVERSIDADE DE BACTERIA E BIOMASSA MICROBIANA EM SOLOS SOB FLORESTA, PASTAGEM E CAPOEIRA NO SUDOESTE DA AMAZÔNIA
}

\begin{abstract}
Os solos da floresta tropical amazônica supostamente abrigam elevada biodiversidade microbiana. Entretanto, as ações antrópicas de corte e queima, especialmente para o estabelecimento de pastagens, induzem mudanças profundas nos ciclos biogeoquímicos. Após alguns anos de uso, a produtividade da gramínea declina, a pastagem é abandonada, tornandose uma vegetação secundária, denominada "capoeira" ou pousio. O objetivo deste trabalho foi avaliar como o desmatamento da floresta amazônica para o estabelecimento de pastagem altera: a diversidade do domínio Bacteria avaliada por PCR-DGGE; a biomassa microbiana e alguns atributos químicos do solo ( $\mathrm{HH}$, umidade, $P, \mathrm{~K}, \mathrm{Ca}, \mathrm{Mg}, \mathrm{Al}, \mathrm{H}+\mathrm{Al}$ e SB); e a influência de variáveis ambientais na estrutura genética de comunidades bacterianas. A pastagem continha entre 30 e $42 \%$ mais carbono total $(C)$ do que a capoeira e aproximadamente $47 \%$ mais $C$ do que a floresta ao longo do ano. O mesmo padrão foi observado para o nitrogênio total $(N)$. A biomassa microbiana na pastagem foi 38 e $26 \%$ maior do que nas áreas de capoeira e floresta, respectivamente, durante a estação chuvosa. O padrão de bandas em $D G G E$ revelou menor número de bandas por área na estação seca, porém as diferenças na estrutura de comunidades bacterianas entre as áreas de estudo foram mais bem definidas do que na estação chuvosa. O perfil de bandas encontrado na floresta esteve mais associado ao teor de Al e às taxas Cmic:Ctot e Nmic:Ntot. Em relação às áreas de pastagem e capoeira, a estrutura do domínio Bacteria esteve mais associada a $\mathrm{pH}$, soma de bases, umidade, $\mathrm{C}$ e $N$ totais e à biomassa microbiana. De modo geral, a biomassa microbiana em solos é influenciada pelos teores de $\mathrm{C}$ e $\mathrm{N}$ totais, os quais estiveram associados ao domínio Bacteria, visto que a comunidade bacteriana é uma fração componente e ativa da biomassa microbiana. Os resultados indicam que a composição genética das comunidades microbianas dos solos da Amazônia mudou ao longo da sequência floresta-pastagem-capoeira.
\end{abstract}

Termos de indexação: mudanças no uso da terra, PCR-DGGE, diversidade bacteriana, biomassa microbiana, análise de componentes principais.

\section{INTRODUCTION}

The huge Amazon River Basin of $4.6 \times 10^{6} \mathrm{~km}^{2}$ contains the largest equatorial forest of the world. Until the 1960s, the anthropogenic impact on this forest in Brazil was not significant. However, by the implementation of development programs for the northern region of the country in the $1970 \mathrm{~s}$, more than $3.7 \times 10^{5} \mathrm{~km}^{2}$ of native vegetation were replaced by pasture for beef production (Cerri et al., 2003). The burning of forest vegetation and land use changes to pastures have increased the soil $\mathrm{pH}, \mathrm{C}$ and $\mathrm{N}$ contents, exchangeable cations and decreases in exchangeable acidity (Moraes et al., 1995; Fernandes et al., 2002).

In several areas of grassland in the Amazon (Veiga, 1995) as well as in other tropical regions (Myers \&
Robbins, 1989), pastures are degraded after few years of use due to overgrazing, invasion of unpalatable weed species, loss of soil fertility and cultivation of inadequate species (Serrão et al., 1982; Serrão \& Homma, 1982; Souza Filho et al., 1991). It is estimated that about 30 to $50 \%$ of the Brazilian Amazon pastures are in an advanced stage of degradation (Fearnside, 2005). The secondary vegetation that gradually develops in such areas is called "capoeira" and has the ability to restore soil nutrients and also to assimilate the carbon released during cutting and burning of the original forest (Zarin et al., 2001; Schroth et al., 2002).

Soil fertility in the Amazon Forest is naturally low and the forest maintenance depends on litter nutrient cycling (Fearnside, 2005). The microbial biomass is 
responsible for the decomposition of soil organic matter, releasing nutrients in inorganic forms that are later absorbed by plant roots (Bijayalaxmi Devi \& Yadava, 2006). Some studies previously carried out in forest-to-pasture chronosequences in the Amazon region have shown that the microbial biomass is reduced three years after pasture establishment, but that their levels are higher in older pastures and reach contents similar to the native forest (Fernandes, 1999; Geraldes et al., 1995). It would be interesting to know whether the soil microbial community also returns to its original state, as in the forest.

Microorganisms play a leading role in soil nutrient cycling and preservation, however little seems to be known about the genetic diversity of many species, due to the limitations in the resolution of the culture methodologies available. Advances in molecular approach such as DNA profiling through PCR-DGGE can provide information regarding the composition of bacterial populations in soils (Clegg, 2006). Small PCR products, commonly up to $400 \mathrm{bp}$, are separated according to their content and distribution of guanine plus cytosine $(\mathrm{G}+\mathrm{C})$ (Muyzer et al., 1993). The fingerprinting pattern is then distributed along a linear denaturing gradient (Fromim et al., 2002).

The aim of this study was to assess the impact that land use changes in the Amazon region have had on the structure of the Bacteria domain. For this purpose, the molecular profiling of bacterial communities was determined and the microbial biomass and soil chemical properties and the influence of environmental variables on the genetic structure of bacterial community were measured.

\section{MATERIALS AND METHODS}

\section{Study sites and sampling}

Field studies were developed on the Fazenda Nova Vida (62 $\left.{ }^{\circ} 49^{\prime} 27^{\prime \prime W} \mathrm{~W} ; 0^{\circ} 10^{\prime} 5^{\prime \prime S}\right), 250 \mathrm{~km}$ south from Porto Velho, in the central region of Rondônia state (Figure 1). The predominant soil type is classified as Argissolo in the Brazilian classification system (Embrapa, 2006) and as Ultisol (Kandiuldults) by the US soil taxonomy. It is a representative soil of the Amazon basin, covering almost $22 \%$ of the Brazilian Amazon basin (Moraes et al., 1995). The Fazenda Nova Vida with an area of approximately 22.000 ha is covered by a mixture of native forest and pastures of different ages. Pastures were established with no mechanical machinery nor chemical fertilization or soil acidity correction. Wood weeds were controlled by cutting the aerial part, removing the residues and burning them to reduce volume and incorporate the ashes into the soil (Feigl et al., 2006).

A sequence was chosen on the farm: (1) a 3 ha plot of native forest, (2) a well-established 20 year-old pasture of Brachiaria brizantha that had been converted from forest by cutting and burning in 1987 , and (3) a fallow site that had been used until 1994 as pasture (Brachiaria brizantha and Panicum maximum), and had gradually converted into a wellestablished secondary growth forest since then. The botanical composition of the fallow area contained 15$18 \%$ woody species (Tabebuia spp., Erisma uncinatum and Vismia guianensis), $12 \%$ Babaçu palm (Orbignya phalerata Mart), 4-11\% herbaceous weeds and $63.5 \%$ of a mixture of Brachiaria brizantha and Pannicum maximum (Feigl et al., 2006).

Soil samples were taken in the rainy season (February 2004) and 6 months later, in the dry season (September 2004). At each evaluated site, five independent composite samples were collected from the surface layer $(0-10 \mathrm{~cm})$. Composite samples were obtained from five subsamples, collected about $50 \mathrm{~m}$ apart, in order to cover a larger area of the same field. Samples were sieved (2-mm mesh) and stored at $3^{\circ} \mathrm{C}$. For the assessment of the bacterial genetic structure, soil samples were maintained at $-80^{\circ} \mathrm{C}$.

\section{Soil chemical properties and microbial biomass}

The laboratory analysis followed the method described by Raij et al. (2001) Soil composite samples were air-dried, large aggregates were broken down and sieved with a 100 mesh $(149 \mu \mathrm{m})$ for total $\mathrm{C}$ and $\mathrm{N}$, by dry combustion on a LECO CN elemental analyzer (furnace at $1,350{ }^{\circ} \mathrm{C}$ in pure oxygen). The fumigation-extraction method was used to estimate microbial $\mathrm{C}$ and $\mathrm{N}$ biomasses (Vance et al., 1987). The Cmic:Ctot and Nmic:Ntot ratios were calculated as percentage fractions of the total $\mathrm{C}$ and $\mathrm{N}$, respectively (Anderson \& Domsch, 1989), and further transformed to $\operatorname{arc} \operatorname{sen}(\mathrm{x} / 100)^{1 / 2}$.

\section{Bacteria diversity}

Total soil DNA extraction and PCR products were generated according to conditions described by Øvreås et al., 1997. PCR products (300 ng) were resolved by DGGE to provide molecular profiles of bacterial communities (Muyzer et al., 1993). The similarity

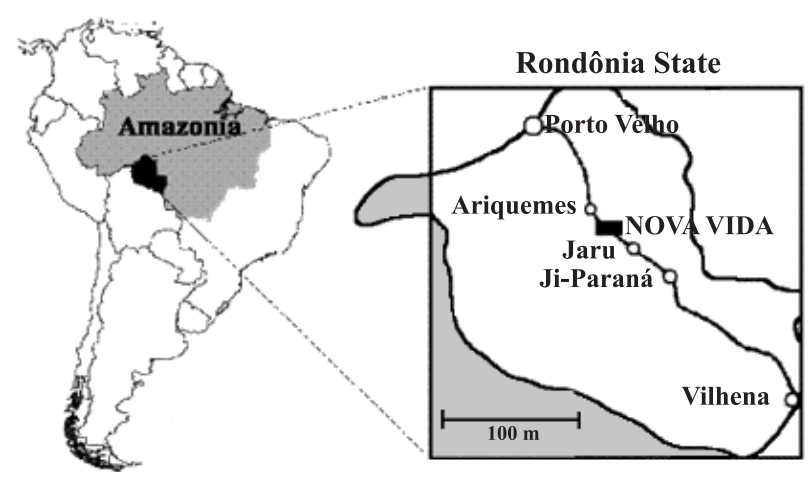

Figure 1. Map of the study site in Rondônia State. 
structure for the bacteria domain was generated from binary data. Dendrograms representing hierarchical linkage levels were constructed based on the Euclidean distance coefficient using Systat 8.0 software.

\section{Experimental design}

The experimental design was randomized and arranged as a factorial scheme 2 seasons x 3 treatments with five replications. Soil chemical properties, microbial biomass, Cmic:Ctot and Nmic:Ntot transformed ratios were statistically evaluated by ANOVA. The means were compared by Tukey's test at $\mathrm{p} \leq 0.05$. The relationship between bacterial community structure, as binary data of DGGE, and the environmental variables was evaluated with the Principal Component Analysis (PCA). A Non-Metric MultiDimensional Scaling (NMDS) based on Jaccard's similarity index was used, to generate the coordinates for indirect PCA analysis. All multivariate analyses were performed using Canoco 4.5 software.

\section{RESULTS AND DISCUSSION}

\section{Soil chemical properties}

The soil was a sandy clay loam with 26-30\% clay, $64-70 \%$ sand and $4-6 \%$ silt at all sites. Forest clearance for conversion to pastures caused changes in the soil chemical properties (Table 1).

The soil $\mathrm{pH}$ in the native forest vegetation was lower than at the sites under grasses. The nitrification process that increases soil $\mathrm{NO}_{3}$ - concentrations is one of major determinant factors of decreased soil $\mathrm{pH}$ in rainforest ecosystems (Neill et al., 2006). The burning of natural vegetation and installation of pastures however increased $\mathrm{pH}$ levels and the exchangeable cations $\mathrm{K}^{+}, \mathrm{Ca}^{2+}$ and $\mathrm{Mg}^{2+}$. Soil $\mathrm{pH}$ increased in the pasture and fallow areas, compared to the native forest. Comparing wet to dry seasons, the $\mathrm{pH}$ levels did not decrease in forest and pasture. Exceptionally, a decrease of $\mathrm{pH}$ values from 5.0 to 4.4 was observed at the fallow site in the dry season (Table 1). These data may be due to the corresponding decrease of $\mathrm{Ca}^{2+}$ and $\mathrm{Mg}^{2+}$ contents, the expressive increase of $\mathrm{Al}$ as well as to the high spatial variability of soil. The soil $\mathrm{pH}$ can be strongly increased by burning of the original forest vegetation, through the input of exchangeable cations in the ashes to the soil. Approximately 5 years after pasture establishment, the soil $\mathrm{pH}$ tends to decrease as a consequence of decreased $\mathrm{K}^{+}, \mathrm{Ca}^{2+}$ and $\mathrm{Mg}^{2+}$ contents. Feigl et al. (1995) and Moraes et al. (1996) reported that soil $\mathrm{pH}$ remains high for more than 15 years after forest clearing, similar to the time of use of pasture in this study.

Moisture ranged from $6.4 \%$ (fallow - dry season) to $24.9 \%$ (pasture - wet season). Soils under pasture covering retained more water than the soils under forest and fallow, which were similar statistically. In the dry season, moisture contents were reduced by $58.5 \%$ in the forest and $66.7 \%$ and $70 \%$ in pasture and fallow, respectively. The content of available $\mathrm{P}$, considered as primary limiting nutrient for plant yield and derived mainly from ashes, was highest in the pasture in the wet season, while in the dry season no differences were found along the sequence.

Aluminum contents and the potential acidity $(\mathrm{H}+\mathrm{Al})$ were higher in the forest than in pasture and fallow areas, which did not differ significantly from each other. The differences of sum of bases among land uses indicated higher $\mathrm{Ca}^{2+}, \mathrm{Mg}^{2+}$ and $\mathrm{K}^{+}$ contents in the pasture and fallow than in the forest, especially in the wet season.

\section{Soil $\mathbf{C}$ and $\mathbf{N}$ contents and microbial biomass}

The soil $\mathrm{C}$ and $\mathrm{N}$ and microbial biomass data are given in table 2 . In the pasture soil the $\mathrm{C}$ and $\mathrm{N}$ contents were higher in the wet than in the dry season. Soil $\mathrm{C}$ and $\mathrm{N}$ gains over time in the wet and dry seasons were higher in the pasture than in fallow areas, which

Table 1. Soil chemical properties (mean \pm SD) of soils of the Fazenda Nova Vida

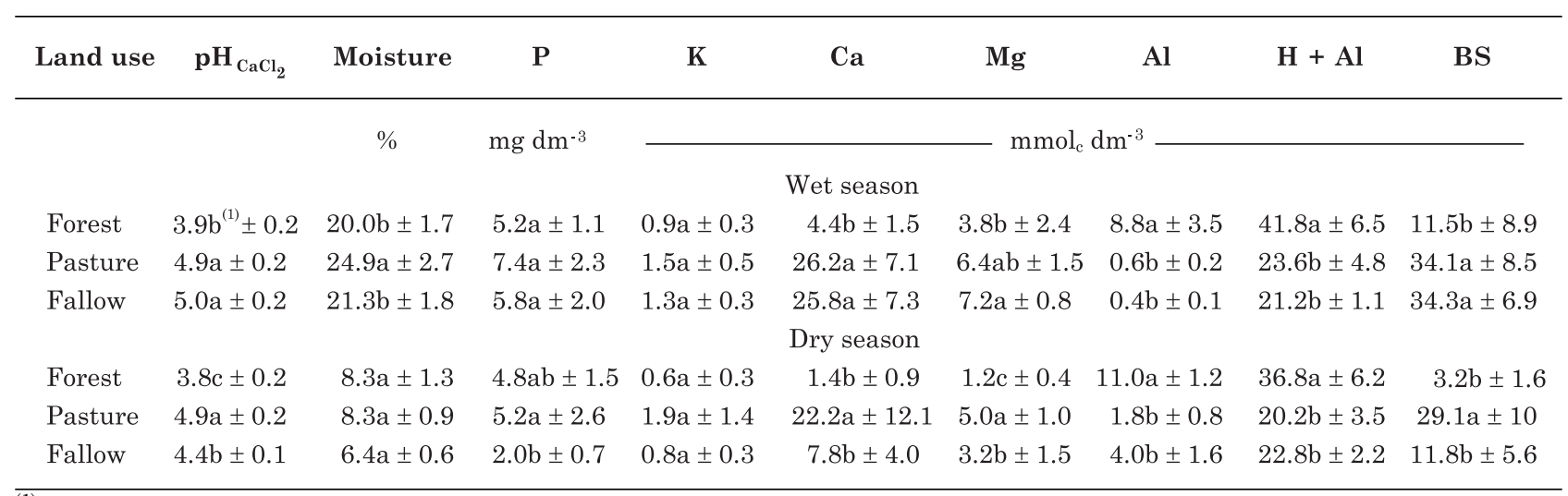

(1) Sites with the same letter in each season did not differ significantly $(\mathrm{p}<0.05)$ by Tukey's test. 
Table 2. Total $\mathrm{C}$ and $\mathrm{N}$ contents, microbial biomass, Cmic:Ctot and Nmic:Ntot ratios (\%) and transformed to $\operatorname{arcsen}(x / 100)^{1 / 2}$ (in parenthesis) of soils of the Fazenda Nova Vida

\begin{tabular}{|c|c|c|c|c|c|c|c|c|}
\hline Land use & Ctot & Ntot & $\begin{array}{c}\mathrm{C} / \mathrm{N} \\
\text { Ratio }\end{array}$ & Cmic & Nmic & Cmic:Ctot & Nmic:Ntot & $\begin{array}{c}\text { Cmid } / \text { mic } \\
\text { Ratio }\end{array}$ \\
\hline & \multicolumn{2}{|c|}{$\mathrm{g} \mathrm{kg}^{-1}$ soil } & & \multicolumn{2}{|c|}{$\longrightarrow \mathrm{mg} \mathrm{kg}^{-1}$ soil } & — & & \\
\hline & & & & Wet s & son & & & \\
\hline Forest & $13.9 \mathrm{~b}^{(1)} \pm 1.7$ & $1.2 \mathrm{~b} \pm 0.1$ & $11.6 \mathrm{ab} \pm 0.5$ & $329.0 \mathrm{~b} \pm 88.3$ & $44.8 \mathrm{a} \pm 15.8$ & $2.3 \mathrm{a} \pm 0.5(0.15 \mathrm{a})$ & $3.6 \mathrm{a} \pm 1.7(0.17 \mathrm{a})$ & $7.3 \mathrm{a} \pm 2.7$ \\
\hline Pasture & $26.5 \mathrm{a} \pm 5.7$ & $2.0 \mathrm{a} \pm 0.6$ & $13.2 \mathrm{a} \pm 2.1$ & $542.0 \mathrm{a} \pm 158.5$ & $62.5 \mathrm{a} \pm 15.7$ & $2.0 \mathrm{a} \pm 0.5(0.14 \mathrm{a})$ & $3.3 a \pm 0.9(0.18 a)$ & $8.7 \mathrm{a} \pm 2.5$ \\
\hline Fallow & $18.3 b \pm 3.3$ & $1.6 \mathrm{~b} \pm 0.4$ & $11.4 \mathrm{~b} \pm 0.9$ & $340.4 \mathrm{~b} \pm 114.0$ & $46.8 \mathrm{a} \pm 19.6$ & $1.9 \mathrm{a} \pm 0.7(0.14 \mathrm{a})$ & $3.0 \mathrm{a} \pm 1.5(0.17 \mathrm{a})$ & $7.3 \mathrm{a} \pm 5.1$ \\
\hline & & & & Dry & son & & & \\
\hline Forest & $10.4 \mathrm{~b} \pm 3.0$ & $0.8 \mathrm{~b} \pm 0.2$ & $13.0 \mathrm{~b} \pm 0.7$ & $58.0 \mathrm{a} \pm 38.9$ & $8.0 \mathrm{a} \pm 2.4$ & $0.5 a \pm 0.3(0.07 a)$ & $1.0 \mathrm{a} \pm 0.3(0.10 \mathrm{a})$ & $7.2 \mathrm{a} \pm 3.1$ \\
\hline Pasture & $19.7 \mathrm{a} \pm 3.9$ & $1.3 \mathrm{a} \pm 0.2$ & $15.1 \mathrm{a} \pm 0.8$ & $35.5 \mathrm{a} \pm 17.3$ & $6.3 \mathrm{a} \pm 2.5$ & $0.2 \mathrm{~b} \pm 0.1(0.04 \mathrm{~b})$ & $0.5 \mathrm{~b} \pm 0.2(0.07 \mathrm{~b})$ & $5.6 \mathrm{a} \pm 3.0$ \\
\hline Fallow & $11.5 b \pm 1.5$ & $0.8 b \pm 0.1$ & $14.3 \mathrm{ab} \pm 1.2$ & $42.2 \mathrm{a} \pm 11.9$ & $8.9 \mathrm{a} \pm 2.3$ & $0.4 \mathrm{ab} \pm 0.1(0.06 \mathrm{ab})$ & $1.1 \mathrm{a} \pm 0.4\left(0.10^{\mathrm{a}}\right)$ & $4.7 \mathrm{a} \pm 1.0$ \\
\hline
\end{tabular}

${ }^{(1)}$ Sites with the same letter in each season were not significantly different $(p<0.05)$ by Tukey's test.

is a degraded pasture, but statistically similar to the forest. Carbon/N ratios varied from 11.4 (fallow wet season) to 15.1 (pasture - dry season) across the sites, which is in the range of values normally described for agricultural soils (Stevenson, 1982).

Grasses of the genus Brachiaria have the potential of adding large amounts of organic $\mathrm{C}$ and $\mathrm{N}$ to the soil, due to continuous root activity and litter deposition (Fernandes et al., 2002; Cerri et al., 2003). However Moraes et al. (1996) did not observe the same pattern of total $\mathrm{N}$ increase as observed for $\mathrm{C}$, possibly due to variations in mineralization and nitrification rates which influence the total $\mathrm{N}$ pools (Piccolo et al., 1994). Serrão \& Toledo (1990) reported that pasture yield in Rondônia as well as in other Amazon regions is closely related to soil fertility and nutrient cycling. The lowest gains of $\mathrm{C}$ and $\mathrm{N}$ at the fallow site may be related to the irregularity of the grass cover. A detailed description of the weed infestation degree weed infestation where - at the study sites? was given by Feigl et al. (2006). Nevertheless, the secondary forest that develops naturally on such abandoned pastures of the Amazon basin can recover part of the $C$ released at cutting and burning the original forest (Neill et al., 1997). In the forest, the litter-dependent nutrient turnover is polycyclic, contributing to lower $\mathrm{C}$ and $\mathrm{N}$ gains in soils of the Fazenda Nova Vida (Feigl et al., 1995; Moraes et al., 1996).

According to data presented in table $2, \mathrm{C}$ and $\mathrm{N}$ immobilized in the microbial biomass followed the same tendency of soil $\mathrm{C}$ and $\mathrm{N}$ in the wet season (Table 1) that is, the values were higher. In the wet season microbial $\mathrm{C}$ and $\mathrm{N}$ to a depth of $10 \mathrm{~cm}$ ranged from $329 \mathrm{mg} \mathrm{kg}^{-1}$ to $542.0 \mathrm{mg} \mathrm{kg}^{-1}$; and from $44.8 \mathrm{mg} \mathrm{kg}^{-1}$ to $62.5 \mathrm{mg} \mathrm{kg}^{-1}$ soil, respectively. The pasture installation increased microbial $\mathrm{C}$ by at least $64 \%$, whereas C concentrations in the forest were similar to fallow. Given that the management regime and quality of organic matter inputs of forest and grasses are different, changing from woody to a more cellulosic substrate, microbial biomass is expected to metabolize and grow easily in soils covered by grasses (Ohtonen et al., 1997).

Nitrogen microbial biomass did not change along the sequence. In the dry season microbial $\mathrm{C}$ and $\mathrm{N}$ ranged from $35.5 \mathrm{mg} \mathrm{kg}^{-1}$ to $58.0 \mathrm{mg} \mathrm{kg}^{-1}$ and from $6.3 \mathrm{mg} \mathrm{kg}^{-1}$ to $8.9 \mathrm{mg} \mathrm{kg}^{-1}$ soil, respectively. Therefore microbial $\mathrm{C}$ and $\mathrm{N}$ were similar across the sites. In conditions of lower soil water content, root activity is drastically decreased and the composition of exudates contains more complex residues, thus limiting microbial growth (Lynch \& Panting, 1980). The land management and soil fertility are thought to be the main causes of variations in the microbial biomass for soils of the Amazon Basin, rather than soil texture or clay content (Serrão \& Toledo, 1990; Fernandes, 1999).

Microbial C:N ratios ranged from 4.7 (fallow - dry season) to 8.7 (pasture - wet season). The ratio of Cmic:Ctot ranged from 1.9 to 2.3 and the Nmic:Ntot ratio from 3.0 to 3.6 in the wet season, respectively. Our data are in agreement with those obtained by Anderson \& Domsch (1989). According to the authors, mean microbial C to total C were $2.3 \%$ for permanent monoculture plots and $2.9 \%$ for crop rotation plots. Values below 2.0 for the ratios Cmic:Ctot and Nmic:Ntot (as observed in the dry season) could be considered critical for soils, reflecting lower availability of substrate to the soil microorganisms (Anderson, 2003). Fernandes (1999) however found higher ranges of Cmic:Ctot and Nmic:Ntot for pastures of different ages on the same ranch. Data transformed to arc sen $(\mathrm{x} / 100)^{1 / 2}$ (in parentheses in Table 2) maintained the same statistical proportion among the treatments, compared to the original data sets of Cmic:Ctot and Nmic:Ntot. This statistical transformation is necessary since the original data expressed as percentage are near zero (Zar, 1999). Microbial communities of long-term crop rotation systems are energetically more efficient, with higher corresponding Cmic:Ctot and Nmic:Ntot values, in comparison to monoculture and forest soil systems (Anderson \& 
Domsch, 1989). In addition, under the acidic conditions of the soil forest, the maintenance requirements of microbial cells are higher and consequently, little biomass can be produced, resulting in low Cmic:Ctot and Nmic:Ntot ratios (Anderson, 2003).

\section{Bacteria diversity}

As expected, PCR with specific primer sets including the forward primer with a G-C clamp (Øvreås et al., 1997) resulted in a single 180-bp fragment. The PCR products were separated by DGGE to assess qualitative bacterial composition. Some band groups, exemplified as I to VI, were chosen to improve the comparison of similar and/or different band profiles.

In figure $2 \mathrm{a}$ (wet season), some bands were found in all soil replicates (I, II). In other words, they were present in the DNA extracted from each sample and indicated the presence of the same bacterial community at the three sites. Pasture was characterized by the presence of band patterns concentrated in PA3 and PA4 (III), and IV is a band profile found in the fallow and in the PA5 replicate of pasture. Forest contained replicates with a high variability of band patterns; therefore FO2 contained more bands than the others $(\mathrm{V})$.

DGGE profiling in the dry season (Figure 3a) revealed more visible differences in the bacterial structure among the sites than in the wet season. Band patterns I and II were observed in almost all samples, except FA1 to FA4. Group III contained bands common to pasture and fallow, and IV and V bands specific to replicates FO1 to FO4 and FO1, respectively. VI was a banding pattern specific to pasture. No specific band profile was found at the fallow site. Independent of the sampling period, similar bands were found among the sites; also, each site had its own particular bands along the DGGE profile.

In the cluster analysis of PCR-DGGE products, the three sites clustered at $65 \%$ similarity for both wet and dry seasons. The data in figure $2 \mathrm{~b}$ show that, in the wet season, bacterial communities were separated in three clusters, except replicate PA2 that tended to group in the forest cluster, whereas replicate PA5 fell into the fallow cluster. In figure $3 b$, the effect of low water content plus history of soil use contributed

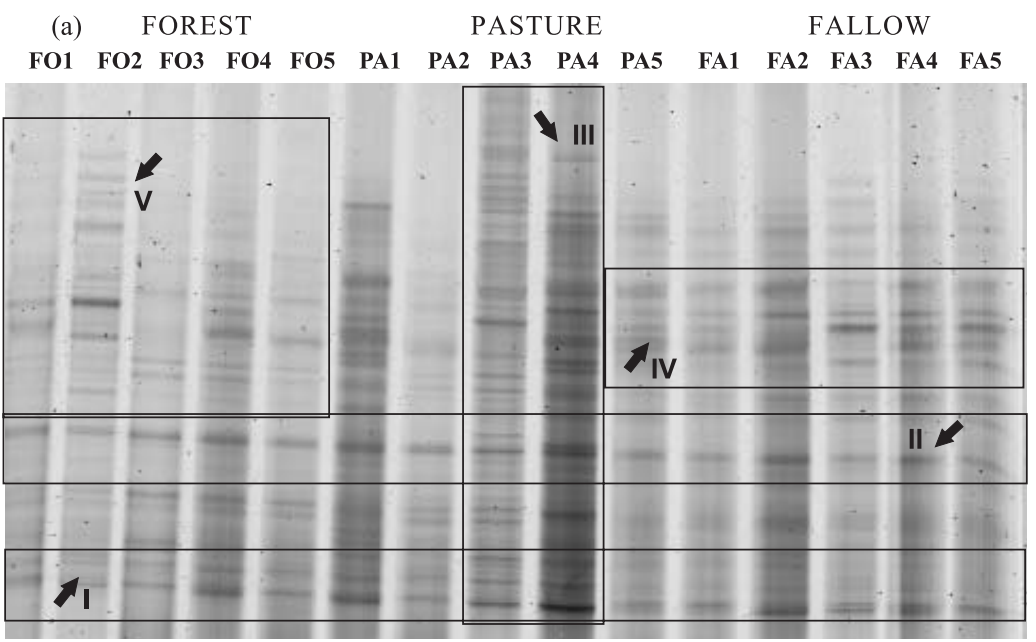

(b)

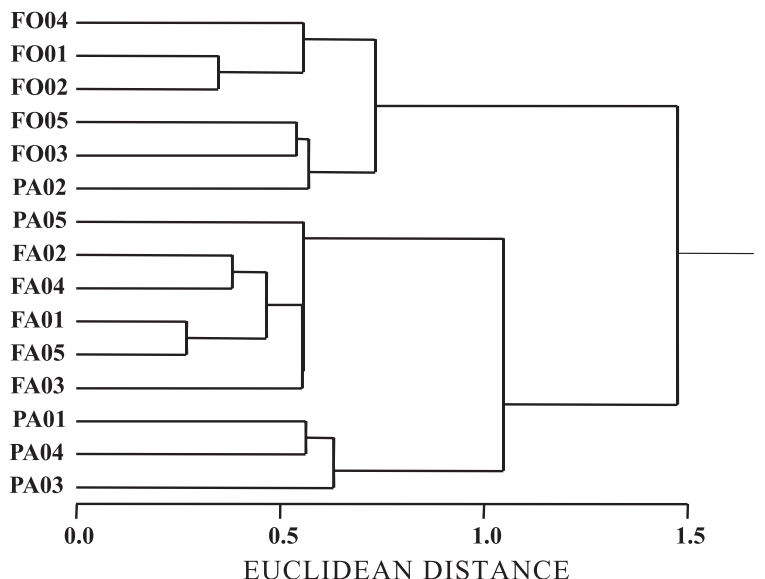

Figure 2. DGGE fingerprinting (a) and cluster analysis of DGGE patterns (b) of Amazon soil samples collected in the wet season. Soil replicates: FO1 to FO5 (forest), PA1 to PA5 (pasture) and FA1 to FA5 (fallow). 
to completely separate the bacterial populations of each site in the dry season. The variation in the composition of microbial community DNA between replicate soil samples was found to be as great as the variation between treatments in field-based studies. The reasons for this variability are not clear; however it is likely that they are attributable to the effect of soil chemical properties plus the contents and composition of organic matter (Ritz et al., 2004; Clayton et al., 2005).

\section{Ordination analysis of bacteria diversity and the microbiological plus soil chemical properties}

Principal component analysis expresses the influence of land use changes on the structure of bacterial populations and the soil properties most closely associated with each site. Biplot representation of the whole dataset provided a grouping of variables, according to their relative position in the planes defined by the first two principal axes. Axis 1 and 2 explained $79.6 \%$ and $20.4 \%$, respectively, of the variability in DGGE data in the wet season (Figure 4a), while in the dry season axis 1 and 2 explained $81.7 \%$ and
$18.3 \%$, respectively, of variability (Figure $4 \mathrm{~b}$ ). In the PCA diagram, positively correlated variables are shown as arrows pointing in the same direction, negatively correlated variables point in opposite directions, and perpendicular vectors are uncorrelated. In addition, the length of the arrow is the relationship between environmental variables and the environmental axes.

The ordination of environmental variables indicated that forest samples were separated from samples of pasture and fallow sites in the wet season (Figure 4a). The Al contents and the Cmic:Ctot and Nmic:Ntot rates were the variables most associated with the genetic structure of bacterial community in the forest. The Al content is associated with lower $\mathrm{pH}$ values, one of the major determinant factors of selection of the microbial composition in different soils, as observed by Fierer \& Jackson (2006). The authors found that of all soil and site variables examined the soil $\mathrm{pH}$ was by far the best predictor of both soil bacterial diversity $\left(\mathrm{r}^{2}=0.70 ; \mathrm{p}<0.0001\right)$ and richness $\left(r^{2}=0.58 ; p<0.0001\right)$, with the lowest levels of diversity and richness observed in acid soils. Kim et

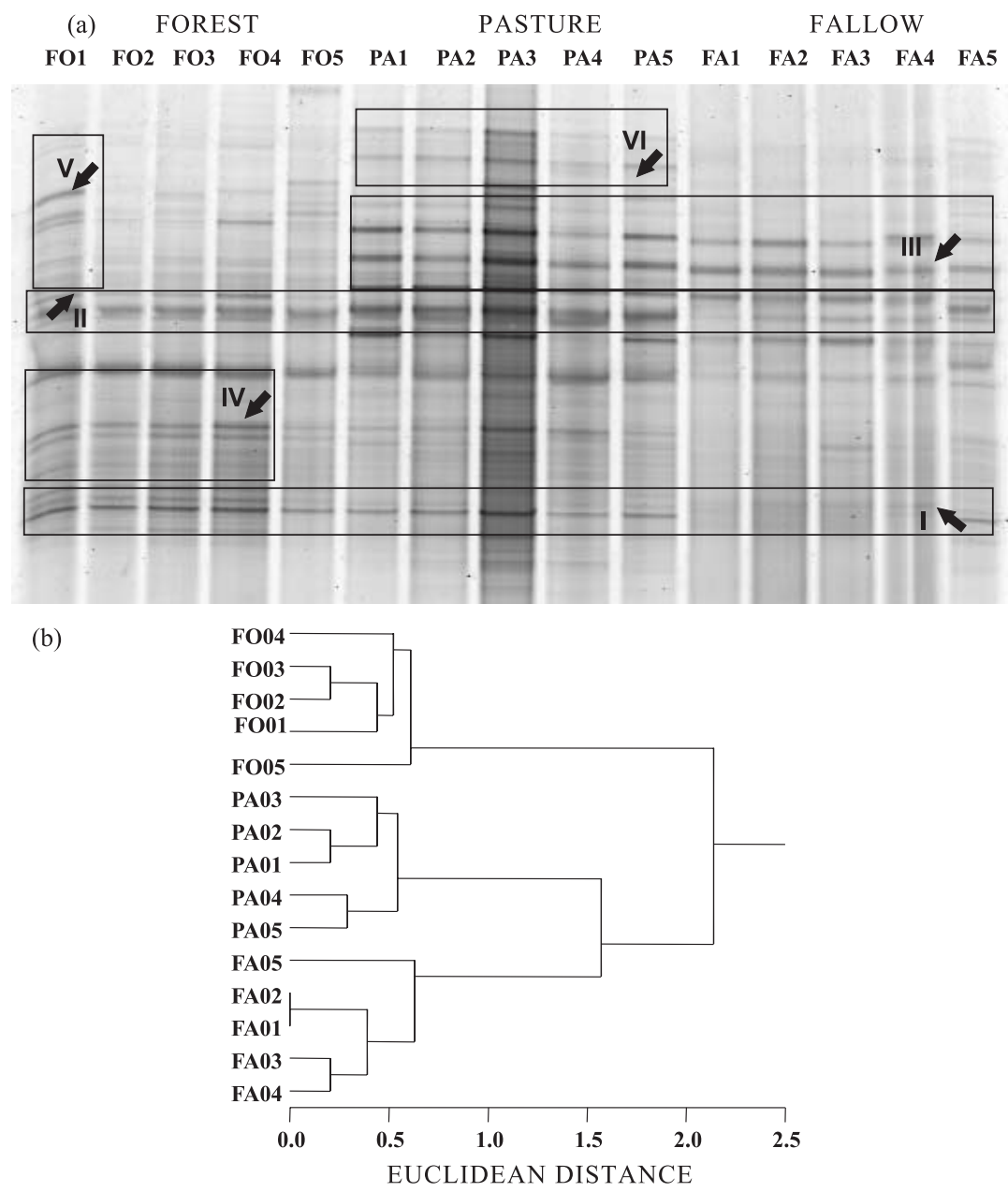

Figure 3. DGGE fingerprinting (a) and cluster analysis of DGGE patterns (b) of Amazon soil samples collected in the dry season. Soil replicates: FO1 to FO5 (forest), PA1 to PA5 (pasture) and FA1 to FA5 (fallow). 

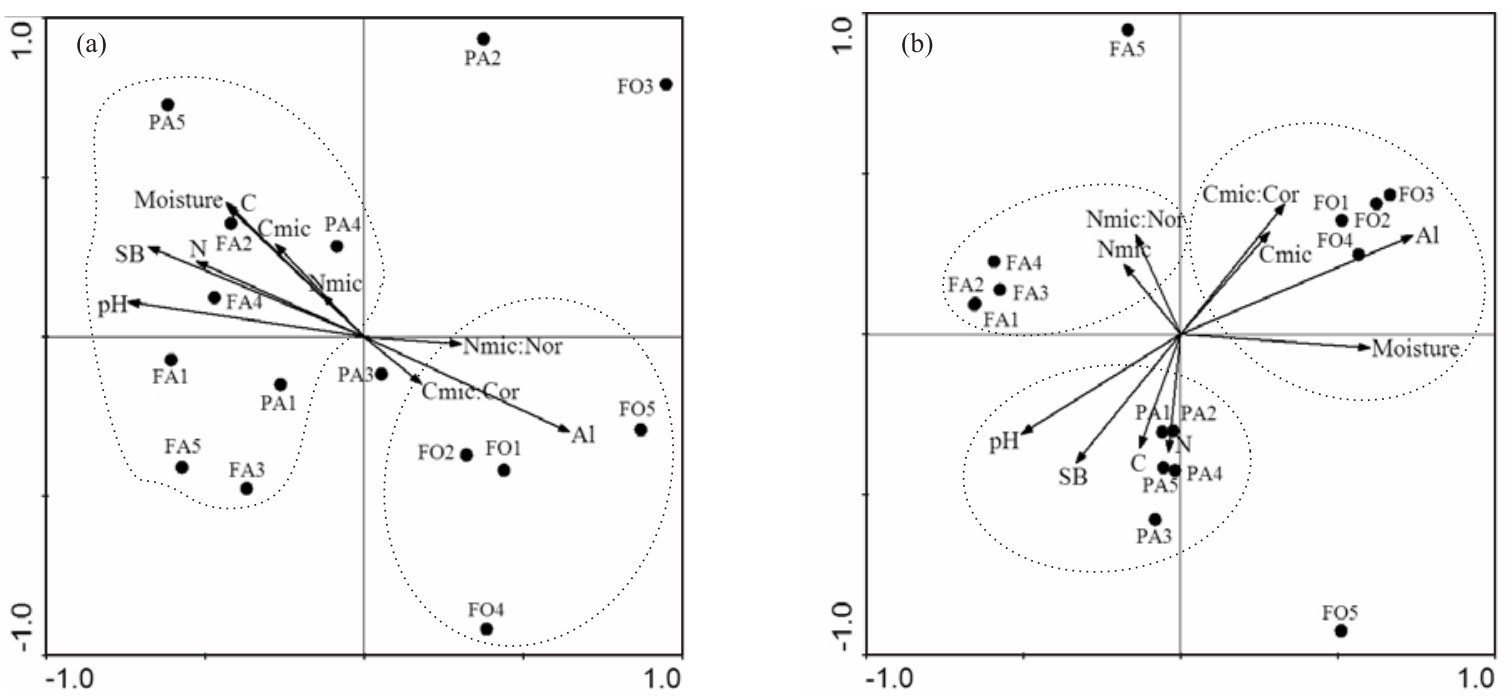

Figure 4. Principal component analysis among land use (forest, pasture and fallow), environmental (moisture, pH, C, N, Al, BS) and microbial parameters (Cmic, Nmic, Cmic:Ctot and Nmic:Ntot) of Amazon soil samples collected in the wet (a) and dry (b) seasons.

al. (2007) demonstrated that the Acidobacterium group represented $50 \%$ bacterial diversity in soil samples from the Amazon forest, Rondônia State. The ratios Cmic:Ctot and Nmic:Ntot were slightly associated to the forest, reflecting the active participation of microbial biomass to recycle nutrients.

The environmental variables $\mathrm{pH}$, sum of bases, moisture, total $\mathrm{C}$ and $\mathrm{N}$, and the microbial biomass were associated to the Bacteria domain at the pasture and fallow sites. Deforestation and land conversion to pastures increased the exchangeable cations and consequently soil $\mathrm{pH}$, due to the large input of ashes (Neill et al., 1997). The soil bulk density of the surface layer is slightly higher under pasture and fallow than under forest, as a result of changes in the pore space distribution and decreased water infiltration and porosity, which contribute to higher moisture contents. On the Fazenda Nova Vida, there are inputs of organic $\mathrm{C}$ and $\mathrm{N}$ to soil from vigorously-growing grasses, and these can maintain an active microbial biomass growth and nutrient turnover (Fernandes et al., 2002; Cerri et al., 2003). In general microbial biomass in soils is influenced by total $\mathrm{C}$ and $\mathrm{N}$, which were associated with the Bacteria domain, since the bacterial community is a component and active fraction of the microbial biomass (Carney \& Matson, 2005). Microbiological data therefore indicate that grassland sites could potentially accumulate organic matter in the soil (Feigl et al., 2006).

According to the PCA analysis, forest samples were associated with $\mathrm{Al}$ contents, moisture, microbial $\mathrm{C}$ and the Cmic:Ctot ratio in the dry season (Figure 4b). Data show that $\mathrm{Al}$ contents remained high in the forest during the year, mainly due to the low $\mathrm{pH}$ (Table 1). The study sites were strongly affected by moisture reduction in the dry season (?), therefore moisture oscillations in the forest were less pronounced. The very close relationship between microbial $\mathrm{C}$ and the Cmic:Ctot ratio shows an active participation of microorganisms in the uptake of labile carbon from the litter layer for maintenance and growth (DiazRavina et al., 1995).

The use of soil as pasture resulted in an increase of $\mathrm{pH}$, sum of bases and total organic $\mathrm{C}$ and $\mathrm{N}$, without seasonal variations. According to the ordination of variables in the PCA diagram, these soil properties were also found associated to the banding profile in the dry season. At the fallow site, the bacteria diversity and composition were weakly associated to microbial $\mathrm{N}$ contents and the Nmic:Ntot ratio, as indicated by the position and length of the arrows. Several studies have reported that rates of microbial $\mathrm{N}$ cycling in old pastures are clearly lower than in the original forest (Piccolo et al., 1994; Neill et al., 1997; Neill et al., 1999; Neill et al., 2006). However, high microbial N that influences the Nmic:Ntot ratio may be considered a strategy of soil microorganisms for maintenance of available nutrients and energy (Cerri et al., 2003).

\section{CONCLUSIONS}

1. The conversion of forest to pasture for cattle grazing and the abandonment to fallow affected soil chemical properties, microbial biomass and the structure of bacterial communities.

2 . Soil bacterial structure varied significantly according to the distinct sources of organic matter and physicochemical properties of each site. 
3. DGGE fingerprinting proved to be a useful index for comparing relative diversity and composition of microbial communities. A focus for future studies would be to investigate the specific link between soil processes and microbial species of functional groups.

\section{ACKNOWLEDGEMENTS}

The authors are indebted to the Fundação de Amparo à Pesquisa do Estado de São Paulo (FAPESP-2004/12689-4) for financial support for this research; to João Arantes Jr, who kindly let the authors work on the Fazenda Nova Vida and provided logistical support; and to Dr. Ciro Abbud Righi for editing the figures .

\section{LITERATURE CITED}

ANDERSON, T.H. \& DOMSCH, K.H. Ratios of microbial biomass carbon to total organic carbon in arable soils. Soil. Biol. Biochem., 21:471-479, 1989.

ANDERSON, T.H. Microbial eco-physiological indicators to assess soil quality. Agric. Ecosys. Environ., 98:285-293, 2003.

BIJAYALAXMI DEVI, N. \& YADAVA, P.S. Seasonal dynamics in soil microbial biomass $\mathrm{C}, \mathrm{N}$ and $\mathrm{P}$ in a mixed-oak forest ecosystem of Manipur, North-east India. Appl. Soil Ecol., 31:220-227, 2006.

CARNEY, K.M. \& MATSON, P.A. Plant communities, soil microorganisms, and soil carbon cycling: Does altering the world belowground matter to ecosystem functioning? Ecosystems, 8:928-940, 2005.

CERRI, C.E.P.; COLEMAN, K.; JENKINSON, D.S.; BERNOUX, M.; VICTORIA, R. \& CERRI, C.C. Modeling soil carbon from forest and pasture ecosystems of Amazon, Brazil. Soil Sci. Soc. Am. J., 67:1879-1887, 2003.

CLAYTON, S.J.; CLEGG, C.D.; MURRAY, P.J. \& GREGORY, P.J. Determination of the impact of continuous defoliation of Lolium perenne and Trifolium repens on bacterial and fungal community structure in rhizosphere soil. Biol. Fert. Soils, 41:109-115, 2005.

CLEGG, C. Impact of cattle grazing and inorganic fertilizer additions to managed grasslands on the microbial community composition of soils. Appl. Soil Ecol., 31:73$82,2006$.

DIAZ-RAVINA, M.; ACEA, M.J. \& CARBALLAS, T. Seasonal changes in microbial biomass and nutrient flush in forest soils. Biol. Fert. Soils, 19:220-226, 1995.

EMPRESA BRASILEIRA DE PESQUISA AGROPECUÁRIA EMBRAPA. Centro Nacional de Pesquisa de Solos. Sistema brasileiro de classificação de solos. 2.ed. Rio de Janeiro, 2006. 306p.

FEARNSIDE, P.M. Desmatamento na Amazônia Brasileira: História, índices e conseqüências. Megadiversidade, 1:113123,2005
FEIGL, B.J.; MELILLO, J.M. \& CERRI, C.C. Changes in the origin and the quality of soil organic matter after pasture introduction in Rondônia (Brazil). Plant Soil, 175:21-29, 1995.

FEIGL, B.; CERRI, C.; PICCOLO, M.; NORONHA, N.; AUGUSTI, K.; MELILLO, J.; ESCHENBRENNER, V. \& MELO, L. Biological survey of a low-productivity pasture in Rondônia state, Brazil. Outlook Agric., 35:199-208, 2006.

FERNANDES, S.A.P. Propriedades do solo na conversão de floresta em pastagem fertilizada e não fertilizada com fósforo na Amazônia (Rondônia). Piracicaba, Centro de Energia Nuclear na Agricultura, Universidade de São Paulo, 1999. 131p. (Tese de Doutorado)

FERNANDES, S.A.P.; BERNOUX, M.; CERRI, C.C.; FEIGL, B.J. \& PICCOLO, M.C. Seasonal variation of soil chemical attributes and $\mathrm{CO}_{2}$ and $\mathrm{CH}_{4}$ fluxes in unfertilized and $\mathrm{P}$ fertilized pastures in an Ultisol of the Brazilian Amazon. Geoderma, 107:227-241, 2002.

FIERER, N. \& JACKSON, R.B. The diversity and biogeography of soil bacterial communities. Proc. Nat. Acad. Sci., 103:626-631, 2006.

FROMIM, N.; HAMELIN, J.; TARNAWSKI, S.; ROESTI, D.; JOURDAIN-MISEREZ, K.; FORESTIER, N.; TEYSSIERCUVELLE, S.; GILLET, F.; ARAGNO, M. \& ROSSI, P. Statistical analysis of denaturing gel electrophoresis (DGE) fingerprinting patterns. Environ. Microb., 4:634643,2002

GERALDES, A.P.A.; CERRI, C.C. \& FEIGL, B.J. Biomassa microbiana de solo sob pastagens na Amazônia. R. Bras. Ci. Solo, 19:55-60, 1995.

KIM, J.S.; SPAROVEK, G.; LONGO, R.M.; MELO, W.J. \& CROWLEY, D. Bacterial diversity of terra preta and pristine forest soil from the Western Amazon. Short communication. Soil Biol. Biochem., 39:684-690, 2007.

LYNCH, J.M. \& PANTING, L.M. Cultivation and the soil biomass. Soil Biol. Biochem., 12:29-33, 1980.

MORAES, J.F.L.; CERRI, C.C.; MELILLO, J.M.; KICKLIGHTER, D.; NEILL, C.; STEUDLER, P. \& SKOLE, D. Soil carbon stocks of the Brazilian Amazon basin. Soil Sci. Soc. Am. J., 59:244-247, 1995a.

MORAES, J.F.L.; VOLKOFF, B.; CERRI, C.C. \& BERNOUX, M. Soil properties under Amazon forest and changes due to pasture installation in Rondônia, Brazil. Geoderma, 70:63-81, 1996

MUYZER, G.; WAAL, E.C. \& UITTERLINDEN, A.G. Profiling of complex microbial populations by denaturing gradient gel electrophoresis analysis of polymerase chain reactionamplified genes coding for $16 \mathrm{~S}$ rRNA. Appl. Environ. Microbiol., 59:695-700, 1993.

MYERS, R.J.K. \& ROBBINS, G.B. Sustaining productive pastures in tropics. 5. Maintaining productive sown grass pastures. Trop. Grasslands, 25:104-110, 1989.

NEILL, C.; PICCOLO, M.C.; CERRI, C.C.; STEUDLER, P.A.; MELILLO, J.M. \& BRITO, M.M.P. Net nitrogen mineralization and net nitrification rates in soils following deforestation for pasture across the southwestern Brazilian Amazon basin landscape. Oecologia, 110:243252, 1997a. 
NEILL, C.; PICCOLO, M.C.; MELILLO, J.M.; STEUDLER, P.A \& CERRI, C.C. Nytrogen dynamics in Amazon forest and pasture soils measured by ${ }^{15} \mathrm{~N}$ pool dilution. Soil Biol. Biochem., 31:567-572, 1999.

NEILL, C.; PICCOLO, M.C.; CERRI, C.C.; STEUDLER, P.A. \& MELILLO, J.M. Soil solution nitrogen losses during clearing of lowland Amazon forest for pasture. Plant Soil, 281:233-245, 2006

OHTONEN, R.; AIKIO, S. \& VÄRE, H. Ecological theories in soil biology. Soil Biol. Biochem., 29:1613-1619, 1997.

ØVREÅS, L.; FORNEY, L.; DAAE, F.L. \& TORSVIK, V. Distribution of bacterioplankton in meromictic lake saelevannet, as determined by denaturing gradient gel electrophoresis of PCR-amplified gene fragments coding for 16S rRNA. Appl. Environ. Microbiol., 63:3367-3373, 1997.

PICCOLO, M.C.; NEILL, C. \& CERRI, C.C. Net nitrogen mineralization and net nitrification along tropical forestto-pasture chronosequence. Plant Soil, 162:61-70, 1994.

RAIJ, B.van; ANDRADE, J.C.; CANTARELLA, H. \& QUAGGIO, J.A. Análise química para avaliação da fertilidade de solos tropicais. Campinas, Instituto Agronômico, 2001.285p.

RITZ, K.; MCNICOL, J.M.; NUNAN, N.; GRAYSTON, S.; MILLARD, P.; ATKINSON, D.; GOLLOTTE, A.; HABESHAW, D.; BOAG, B.; CLEGG, C.D.; GRIFFITHS, B.S.; WHEATLEY, R.E.; GLOVER, L.A.; MCCAIG, A.E. \& PROSSER, J.I. Spatial structure in soil chemical and microbiological properties in an upland grassland. FEMS Microbiol. Ecol., 49:191-205, 2004.

SCHROTH, G.; D’ ANGELO, S.A.; TEIXEIRA, W.G.; HAAG, D. \& LIEBEREI, R. Conversion of secondary forest into agroforestry and monoculture plantations in Amazônia: Consequences for biomass, litter and soil carbon stocks after 7 years. For. Ecol. Manag., 163:131-150, 2002.
SERRÃO, E.A.S. \& HOMMA, A.K.O. Recuperação e melhoramento de pastagens cultivadas em áreas de floresta Amazônica. Belém, Embrapa/CPATU, 1982. 22p.

SERRÃO, E.A.S.; FALESI, I.C.; VEIGA, J.B. \& TEIXEIRA NETO, J.F. Produtividade de pastagens cultivadas em solos de baixa fertilidade das áreas de floresta amazônica brasileira. In: TERGAS, L.E; SANCHEZ, P.A. \& SERRÃO, E.A.S. Produção de pastagens em solos ácidos dos trópicos. Brasília, CIAT/Embrapa, 1982. p.219-251.

SERRÃO, E.A. \& TOLEDO, J.M. The search for sustainability in Amazonian pastures. In: ANDERSON, A.B. Alternatives to deforestation: Steps towards sustainable use of the Amazon Rain Forest. New York, Columbia University Press, 1990. p.195-214.

SOUZA FILHO, A.P.S.; TEIXEIRA NETO, J.F. \& VEIGA, J.B. Adubação de pastagens de capim colonião em degradação, em Santana do Araguaia (Pará). Belém, Embrapa/CPATU, 1991. $16 \mathrm{p}$

STEVENSON, F.J. 'Biochemistry of the formation of humic substances'. Humus chemistry: Genesis, composition, reactions. New York, John Wiley \& Sons, 1982. p.195220 .

VANCE, E.D.; BROOKES, P.C. \& JENKINSON, D.S. An extraction method for measuring soil microbial biomass C. Soil Biol. Biochem., 19:703-707, 1987.

VEIGA, J.B. Reabilitação de áreas de pastagens degradadas. In: SIMPÓSIO SOBRE MANEJO E REABILITAĈ̃O DE ÁREAS DEGRADADAS E FLORESTAS SECUNDÁRIAS NA AMAZÔNIA. Santarém, 1995.

ZAR, J.H. Biostatiscal analysis. 4.ed. Englewood Cliffs, Prentice Hall Upper Saddle River, 1999. 523p.

ZARIN, D.J.; DUCEY, M.J.; TUCKER, J.M. \& SALAS, W.A. Potential biomass accumulation in Amazonian regrowth forests. Ecosystems, 4:658-668, 2001. 